\title{
Assignment of the ZIP kinase gene to human chromosome 19p13.3 by somatic hybrid analysis and fluorescence in-situ hybridization
}

Received: April 24, 1998/Accepted: May 29, 1998

\begin{abstract}
A cDNA for a putative member of the serine/ threonine kinase family was cloned from an adult human testis cDNA library. The predicted translation product was identical to ZIP kinase, which has been suggested to play an important role in the induction of apoptosis. The messenger RNA was ubiquitously expressed in various tissues. The chromosomal location of the gene was determined by fluorescence in-situ hybridization and polymerase chain reaction-based analyses with both a human/rodent monochromosomal hybrid cell panel and a radiation hybrid mapping panel. This gene was mapped on the q13.3 region of chromosome 19.
\end{abstract}

\section{Introduction}

We have systematically screened serine/threonine protein kinases by reverse transcription-polymerase chain reaction (PCR) amplification with degenerated primers corresponding to the conserved regions of the protein kinase domain (Saito et al. 1995), and we have identified several independent kinase genes (Saito et al. 1995,1997; Seki et al. 1997). One of them showed a striking sequence homology to ZIP kinase reported by another research group (Kawai et al. 1998; DDBJ/EMBL/GenBank accession no., AB007144). Kawai et al. (1998) reported that the ZIP kinase induced morphological changes in apoptosis in mammalian cells when overexpressed, suggesting that it plays an important

T. Saito $(\square) \cdot$ N. Seki $\cdot$ A. Hayashi $\cdot$ S. Kozuma $\cdot$ A. Hattori $\cdot$

T. Hori

Genome Research Group, National Institute of Radiological

Sciences, Anagawa 4-9-1, Inage-ku, Chiba 263-8555, Japan

Tel. +81-43-206-3135; Fax +81-43-251-9818

e-mail: t_saito@nirs.go.jp

M. Ohira

Division of Biochemistry, Chiba Cancer Center Research Institute,

Chiba, Japan

* These authors contributed equally to this work role in the induction of apoptosis. Thus, the malfunction of ZIP kinase may cause unexpected cell growth. Precise investigation of the expression profiles and chromosome mapping of ZIP kinase could be important in elucidating the role of the kinase in tumorigenesis.

\section{Results and discussion}

In the present study, chromosomal assignment of ZIP kinase gene was done by PCR analysis of human/rodent somatic cell hybrid panels and radiation hybrid panels. The specific amplified PCR product for human was detected only from the hybrid containing human chromosome 19 (Fig. 1a). We performed further mapping analysis using a PCR-based radiation hybrid panel (Genebridge 4; Research Genetics, Huntsville, AL, USA) with the same primers as those used in the assay for the human/rodent somatic cell hybrid panel.

Statistical analysis of the radiation hybrid data was performed using the RHMAPPER software package (http:// www-genome.wi.mit.edu/cgi-bin/contig/rhmapper. $\mathrm{pl})$. The data vector for the ZIP kinase gene was 0010000001 $\begin{array}{llll}1000000010 & 1000011110 & 0100000001 & 1010110100\end{array}$ $\begin{array}{lllll}1021010010 & 0000000010 & 1110001000 & 0001011000 & 000\end{array}$ and the consequent report indicated that the gene was mapped between markers WI-6480 and AFMA134XB9, both of which have been cytogenetically mapped to $19 \mathrm{p} 13$. The position of the gene is $8.56 \mathrm{cR}$ proximal from WI-6480.

To confirm the PCR-based chromosome mapping by an independent approach, we performed R-banding fluorescence in-situ hybridization (FISH), using P1 phage DNA containing the ZIP kinase gene, as described previously (Saito et al. 1995,1997; Seki et al. 1997). The P1 clone was isolated by a method described previously (Ohira et al. 1997). Clear doublet signals were consistently demonstrated on the $\mathrm{p} 13.3$ position of chromosome 19. The typical pattern of the FISH experiment is represented in Fig. 1b,c. Thus, the gene was judged to be mapped on 19p13.3. 
Fig. 1a-c Chromosome mapping of the novel human ZIP kinase gene. a Polymerase chain reaction (PCR) analysis of human/rodent hybrid cell panels. A PCR screening of a humanrodent somatic cell hybrid panel was performed to map the ZIP kinase gene to human chromosome 19. DNA of the human-rodent somatic cell hybrid panel was purchased from the National Institute of General Medicine Service, Coriell Cell Repositories (Palo Alto, CA, USA). Human, mouse, and hamster genomic DNAs were also included as controls in the assay. Primers used for PCR amplification correspond to (5'-GCGGAGTGGGAGGAGCTGGAG-3') and (5'-ACCCCGCCGAATTGTCCGTGCA-3')(PCR product size, $260 \mathrm{bp}$ ). PCR was carried out in a final volume of $10 \mu \mathrm{l}$ containing $1 \times$ LA-PCR buffer (Takara, Kyoto, Japan), $2 \mu \mathrm{M}$ each primer, $200 \mu \mathrm{M}$ each dNTP, 50 ng template DNA, and 0.01 units of LA-Taq DNA polymerase (Takara). Temperature and time profiles were: 30 cycles at $95^{\circ} \mathrm{C}$ for $20 \mathrm{~s}$ and at $66^{\circ} \mathrm{C}$ for $1 \mathrm{~min}$. Numbers at the top of each lane indicate the human chromosome contained in each somatic cell hybrid. b,c Fluorescence in-situ hybridization (FISH) of the ZIP kinase gene. FISH was carried out using a biotinylated hybridization probe made from a $\mathrm{P} 1$ phage clone harboring the ZIP kinase gene. Arrows indicate the hybridization signals on human chromosome 19p13.3. The metaphase spreads were photographed with a Nikon (Tokyo, Japan) B-2A filter
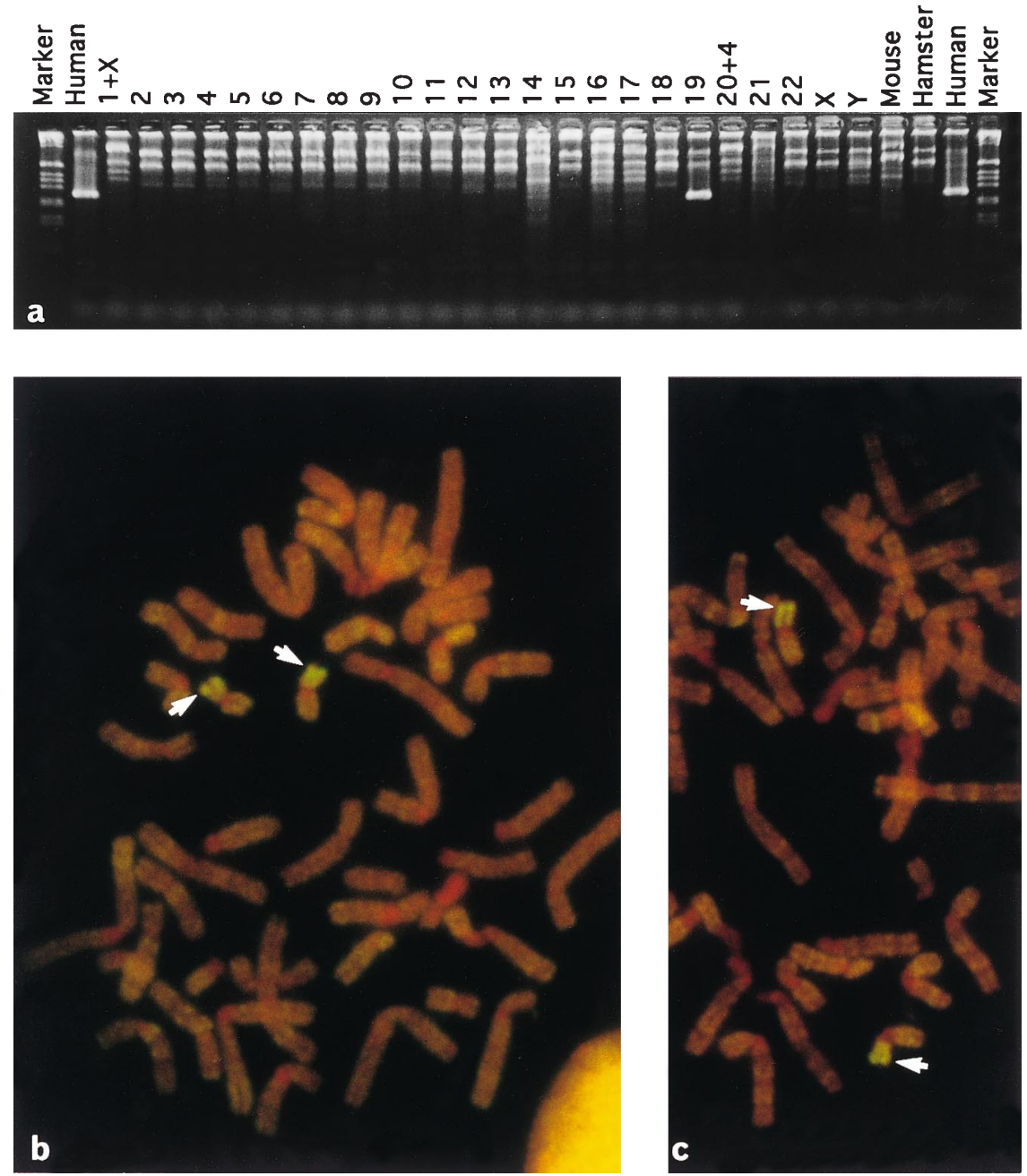

We note here three candidate malignancies in which ZIP kinase might be involved. The genetic locus of PeutzJeghers (PJ) syndrome, an autosomal-dominant disorder characterized by melanocytic macules on the lips, multiple gastrointestinal hamartomatous polyps, and an increased risk of various neoplasms, was mapped to the p13.3 region of chromosome 19 by linkage analysis (Nakagawa et al. 1998; Olschwang et al. 1998). Recently, a novel serine/ threonine kinase STK11 was isolated from the region, and sequence analysis of the STK11 revealed that germline mutations of the gene caused manifestations of PJ syndrome (Jenne et al. 1998). Adenoma malignum (AM) is one of the malignant tumors commonly associated with PJ syndrome. A loss of heterozygosity $(\mathrm{LOH})$ study of a sporadic case of AM revealed that a putative tumor suppressor gene for AM was located at D19S216 on chromosome 19p13.3, a distinct region for $\mathrm{PJ}$ syndrome, and that the gene(s) played an important role in AM tumorigenesis (Lee et al. 1998) (candidate 1).

Structural rearrangements of chromosome 19 are also observed in pancreatic carcinomas, resulting in a high frequency of 19p13.3 losses, suggesting that the gene(s) of importance in the development of pancreatic carcinomas are located in the region (Hoglund et al. 1998) (candidate

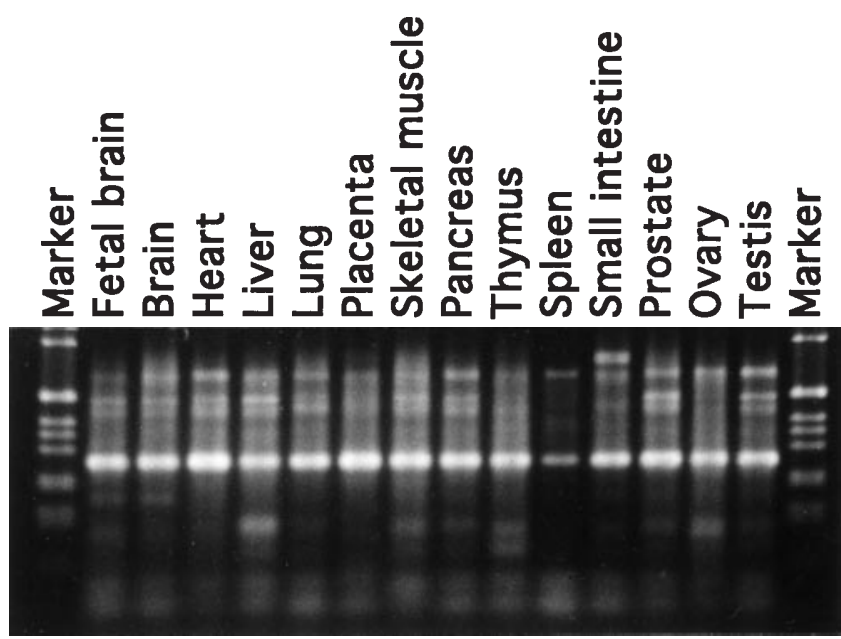

Fig. 2 Reverse transcriptase-PCR in various human tissues was performed with the same primer set as that used for the analysis shown above, and for thermal cycle profile was described for the chromosome mapping shown in Fig. 1. Templates of the human tissue poly(A) RNAs were purchased from Clontech (Palo Alto, CA, USA) 
2). The most common nonrandom translocation of childhood pre-B acute lymphoblastic leukemia is $\mathrm{t}(1 ; 19)(23 ; \mathrm{p} 13)$, which frequently involves the $E 2 A$ gene at 19p13.3 (Nourse et al. 1990). A novel pre-B cell line, TS-2, has been identified with $\mathrm{t}(1 ; 19)$ translocation not involving the $E 2 A$ gene (Yoshinari et al. 1998). These findings suggest that TS-2 may have a genetic abnormality involving uncharacterized gene(s) at 19p13.3 distinct from the E2A gene (Yoshinari et al. 1998) (candidate 3).

Considering its ubiquitous expression in a wide variety of human tissues (Fig. 2), ZIP kinase seems to be involved in a basic housekeeping function in cells. Our precise chromosomal positioning data for the gene could contribute toward on-going positional candidate approaches for the above-mentioned disease genes linked to this genomic locus.

\section{References}

Hoglund M, Gorunova L, Andren-Sandberg A, Dawiskiba S, Mitelman F, Johansson B (1998) Cytogenetic and fluorescence in situ hybridization analyses of chromosome 19 aberrations in pancreatic carcinomas: frequent loss of 19p13.3 and gain of 19q13.1-13.2. Genes Chromosomes Cancer 21: 8-16

Jenne DE, Reimann H, Nezu J, Friedel W, Loff S, Jeschke R, Muller O, Back W, Zimmer M (1998) Peutz-Jeghers syndrome is caused by mutations in a novel serine threonine kinase. Nature Genet 18 38-43

Kawai T, Matsumoto M, Takeda K, Sanjo H, Akira S (1998) ZIP kinase, a novel serine/threonin kinase which mediates apoptosis. Mol Cell Biol 18: 1642-1651
Lee JY, Dong SM, Kim HS, Kim SY, Na EY, Shin MS, Lee SH, Park WS, Kim KM, Lee YS, Jang JJ, Yoo NJ (1998) A distinct region of chromosome 19p13.3 associated with the sporadic form of adenoma malignum of the uterine cervix. Cancer Res 58: 1140-1143

Nakagawa H, Koyama K, Tanaka T, Miyoshi Y, Ando H, Baba S, Watatani M, Yasutomi M, Monden M, Nakamura Y (1998) Localization of the gene responsible for Peutz-Jeghers syndrome within a 6cM region of chromosome 19p13.3. Hum Genet 102: 203-206

Nourse J, Mellentin JD, Galili N, Wilkinson J, Stanbridge E, Smith SD, Cleary ML (1990) Chromosomal translocation $\mathrm{t}(1 ; 19)$ results in synthesis of a homeobox fusion mRNA that codes for a potential chimeric transcription factor. Cell 60: 535-545

Ohira M, Seki N, Nagase T, Suzuki E, Nomura N, Ohara O, Hattori M, Sakaki Y, Eki T, Murakami Y, Saito T, Ichikawa H, Oki M (1997) Gene identification in 1.6-Mb region of the Down syndrome region on chromosome 21. Genome Res 7: 47-58

Olschwang S, Markie D, Seal S, Neale K, Phillips R, Cottrell S, Ellis I, Hodgson S, Zauber P, Spigelman A, Iwama T, Loff S, McKeown C, Marchese C, Sampson J, Davies S, Talbot I, Wyke J, Thomas G, Bodmer W, Hemminki A, Avizienyte E, de la Chapelle A, Aaltonen L, Tomlinson I, et al. (1998) Peutz-Jeghers disease: Most, but not all, families are compatible with linkage to 19p13.3. J Med Genet 35: 4244

Saito T, Seki N, Matsuda Y, Kitahara M, Murata M, Kanda N, Nomura N, Yamamoto T, Hori T (1995) Identification of the human ERK gene as a putative receptor tyrosine kinase and its chromosomal localization to $1 \mathrm{p} 36.1$ : a comparative mapping of human, mouse, and rat chromosomes. Genomics 26: 382-384

Saito T, Seki N, Ishii H, Ohira M, Hayashi A, Kozuma S, Hori T (1997) Complementary DNA cloning and chromosomal mapping of a novel phosphatidylinositol kinase gene. DNA Res 4: 301-305

Seki N, Nimura Y, Ohira M, Saito T, Ichimiya S, Nomura N, Nakagawara A (1997) Identification and chromosome assignment of a human gene encoding a novel phosphatidylinositol-3 kinase. DNA Res 4: 355-358

Yoshinari M, Imaizumi M, Eguchi M, Ogasawara M, Saito T, Suzuki H, Koizumi Y, Cui Y, Sato A, Saisho T, Ichinohasama R, Matsubara Y, Kamada N, Inuma K (1998) Establishment of a novel cell line (TS2 ) of pre-B acute lymphoblastic leukemia with a t(1;19) not involving the E2A gene. Cancer Genet Cytogenet 101: 95-102 